BULLETIN Bulletin hispanique

HISPANIQUE Université Michel de Montaigne Bordeaux

119-1 | 2017

Autorité et pouvoir dans le théâtre du Siècle d'Or

\title{
Mi vida/anda de un hilo pendiente
}

Precarity and Power in the Dramatic Works of Juan Pérez de Montalbán

John T. Cull

\section{(2) OpenEdition}

\section{Journals}

Edición electrónica

URL: http://journals.openedition.org/bulletinhispanique/4783

DOI: 10.4000/bulletinhispanique.4783

ISBN: 979-10-300-0142-6

ISSN: 1775-3821

Editor

Presses universitaires de Bordeaux

Edición impresa

Fecha de publicación: 15 junio 2017

Paginación: 101-116

ISBN: 979-10-300-0141-9

ISSN: 0007-4640

Referencia electrónica

John T. Cull, « Mi vida/anda de un hilo pendiente », Bulletin hispanique [En línea], 119-1 | 2017, Publicado

el 15 junio 2020, consultado el 11 septiembre 2020. URL : http://journals.openedition.org/

bulletinhispanique/4783; DOI : https://doi.org/10.4000/bulletinhispanique.4783 


\title{
Mi vida / anda de un hilo pendiente: Precarity and Power in the Dramatic Works of Juan Pérez de Montalbán
}

\author{
JoHn T. Cull \\ College of the Holy Cross
}

Le drame espagnol du Siècle d'Or aborde très fréquemment le thème de l'ascension et de la chute du privado, ou favori du roi: c'est le cas pour de nombreuses pièces de Juan Pérez de Montalbán. La présente étude se propose d'explorer la représentation de la précarité du favori dans l'œuvre du dramaturge, en portant une attention particulière aux apariencias emblématiques.

Mots-clés: Juan Pérez de Montalbán, précarité, privanza.

El drama español del Siglo de Oro cultivó con una frecuencia sorprendente el tema de la subida y caída del privado. Es un tema que aparece en muchas de las obras dramáticas de Juan Pérez de Montalbán. El análisis presente explora la representación de la precariedad del privado en la obra del dramaturgo con un enfoque especial en las apariencias dramáticas emblemáticas.

Palabras clave: Juan Pérez de Montalbán, precariedad, privanza.

Spanish drama of the Golden Age exploited with great frequency the theme of the rise and fall of the privado, or royal favourite. It is a theme that appears in many plays by Juan Pérez de Montalbán. This study explores the dramatist's depiction of the precariousness of the favourite, with a special focus on emblematic discovery scenes.

Keywords: Juan Pérez de Montalbán, precarity, privanza. 
Precarity is a term that has been coopted by modern critics to emphasize 1 economic uncertainties in the workplace and the attendant insecurities that ensue as a result of un- or under employment: «Precarity is life lived in relation to a future that cannot be propped securely upon the past. [...] Life and work, and their dependence upon one another, are often imagined as increasingly precarious, their futures shadowed by pervasive terror as well as everyday anxieties about work» (Ridout and Schneider, 5) ${ }^{1}$. In this study, however, I am interested in exploring a notion of the precarious in the dramatic works of Juan Pérez de Montalbán more along the lines of the definition provided in the Diccionario de Autoridades (1737): «Precario. adj. que en lo forense se aplica a lo que solo se possee como en préstamo, y a voluntad de su dueño». Drama is, to a great extent, an exploration of the confrontation between individuals afflicted with human failings and precarious circumstances that test their mettle. In comedy, the individual triumphs over the problematic obstacles, while in tragedy the impediments prove to be too difficult to overcome. In Spanish drama of the Golden Age, tragic precarity, the sword of Damocles that dangles over the head of those who enjoy favor and power, is the theme of an extraordinary number of plays, and most particularly in those that deal with privanza $a^{2}$.

Economic precarity is, however, applicable to Spanish Golden Age drama. Perhaps no profession, ancient or modern, has ever been more dependent on the fickle twists of fate as the theatrical industry, where the reputation and livelihood of so many interested players [emphasis added] hang delicately in the balance. Margaret R. Greer and Andrea Junguito remind us that in the Spanish Golden Age "the 'blood' that kept that theatrical heart pumping, nourishing it and the social organism it served, was money - the cash to buy scripts from playrights, pay actors, buy costumes, and pay the theatre lease» (2004: 32). The success or failure of a theatrical troupe did not rest solely on its artistic talents nor the craft of the poets whose manuscripts provided the consumer goods that fed their business enterprise, but rather on the unpredictable tastes of the consumers, «a double public, those members of the public who voted with their feet, voices, whistles, and sometimes more solid projectiles; and an aristocratic elite that exercised its control through the Council of Castile and the municipal councils, the cofradias, and other forms of institutional or personal patronage» (Greer and Junguito 2004: 36-37).

We need look no further than Quevedo's Buscón (1626) for evidence of the precarity of the existence of Golden Age representantes. Pablos joins the ranks

1. The Drama Review 56.4 (2012) dedicates an entire special issue to the topic of precarity and performance.

2. Many studies have been dedicated to the theme of privanza in Spanish Golden Age drama. For Calderón de la Barca, see Sáez (2015); for Lope de Vega, see Carreño-Rodríguez (2005), Peale (2004), Ferrer Vals (2004) and Atienza (2009); for Tirso de Molina, see Weimer (1998); for Mira de Amescua, see Wise (2014) and Oriel (1996); for Ruiz de Alarcón, see Campell (2016); for Quevedo's play Cómo ha de ser el privado, see De Armas (2004) and Hernández Araico (2000); for more general studies, see Profeti (2010) and Bradner (1971); for monographic volumes that include studies on privanza in Golden Age drama, see the collections edited by MallorquíRucalleda (2015) and Usunáriz and Williamson (2013). 
of an itinerant company and rises through its hierarchy. He experiences all the highs and lows of the theatrical profession. The protagonist describes the consequences of appearing in a disastrous comedy that was fashioned from pilfered bits and pieces of the works of other playwrights:

quiso Dios que empezaba por una guerra, y salía yo armado y con rodela, que, si no, a manos de mal membrillo, tronchos y badeas, acabo. No se ha visto tal torbellino, y ello merecíalo la comedia, porque traía un rey de Normandía sin propósito, en hábito de ermitaño, y metía dos lacayos por hacer reír, y al desatar de la maraña no habia más de casarse todos y allá vas. Al fin, tuvimos nuestro merecido (ed. Ynduráin, 260).

But Pablos also achieves great success and wealth during his brief theatrical career, only to have it all come crashing down around him when the company disbands after the arrest of its autor: «Sucedio, pues, que a mi autor (que siempre paran en esto), sabiendo que en Toledo le habia ido bien, le ejecutaron no sépor qué deudas y le pusieron en la cárcel, con lo cual nos desmembramos todos y echó cada uno por su parte» (ed. Ynduráin, 265-266).

The precarious situation of the privado is a constant in Spanish Golden Age comedia, and this popular theme is also present in the plays of Juan Pérez de Montalbán. Even though he lamented in his dedication of La doncella de labor that: «oy está la Comedia tan politica, que viene a ser como vn sermón en consonantes (Primero tomo de las comedias..., f. 88v), Lope's friend and disciple exploited the discourse of political power and authority extensively in his dramatic production, especially in those plays with a historical or pseudohistorical protagonist whose rise and fall would have been familiar to the majority of the heterogeneous theater-going public, endlessly fascinated by the constant turning of the wheel of fortune.

In Los templarios, Pérez de Montalbán chronicled a collective case of the rise and fall from power. The Templar Order, founded in the Middle Ages to protect Christians on religious pilgrimages to Jerusalem, amassed extraordinary power and wealth over the course of the two centuries of its existence. Jacques de Molay (Jacobo de la Mota in the play), the Grand Master of the Knights Templar and reformer of the Order at the time that Pope Clement V ordered its dissolution, was arrested, tortured and burned at the stake in Paris in 1314.

In our dramatist's rendition of the exemplary tale of the consequences of the abuse of power, Germano is the protagonist whose individual fate as caudillo de los Templarios embodies the plight of the Order as a whole. When the reformminded Grand Master informs the Templars that the Pope has issued a new rule, "Que hagan voto de pureza» (74r), the downward spiral of the once virtuous protagonist is set in motion because, as the gracioso Gilote explains: "que no ay castidad segura / en santos que comen bien» (f. 75r). When Jacobo learns that his two captains, Albante and Germán are cohabiting with Flora and Casandra, he orders that they be stripped of their swords and habits and imprisoned.

Lust, however, is not the sole reason given for the fall of the Templars. Gilote, fulfilling the gracioso's role as the conveyor of truth, imputes the corruption of the Templar Order to the evils of wealth: 


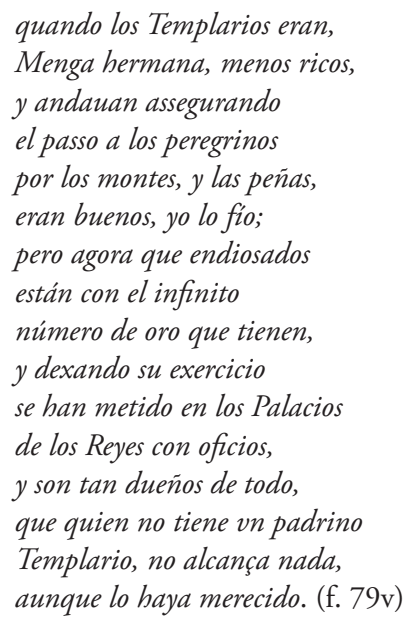

In the final act of the play the king and Pope issue the order for the execution of all the Templars and the prohibition of their Order. Jacobo counsels prudence, advising the Pope to punish only those Templars who are corrupt: «Para hazer bien vuestro oficio, / porque estándome juzgando / de Dios estáis imitando / el poder, y el exercicio» (f. 83r). Pope Clement, however, invokes the doctrine of Reason of State, although the term is not explicitly enunciated: "Que mueran malos y buenos / para que los malos mueran, / y assi estará Dios vengado» (f. 83v). What is more, he compares the danger that the Templars represent to the Faith as a cancer that must be extirpated:

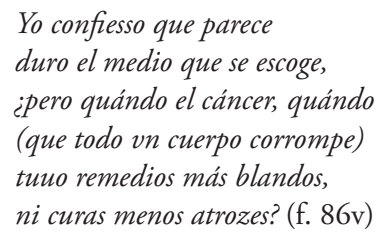

He concludes that the Templars must be totally eradicated, for: "La Iglesia no admite dudas, / la virtud no aprueua errores, / la Fé no consiente achaques» (f. 86v).

The spectator of Los templarios experiences a true and conflictive catharsis. Inherent in the drama's subtext is a warning to the agents of authority to be wary of absuing their powers. However, the injustice of the fate suffered by the innocent Grand Master and the majority of the members of the Order is reflected in a visually symbolic discovery scene that effectively closes the play and leaves the audience to ponder the nature of justice and the consequences of unchecked power and wealth: "Tocan tristemente, y descubren unos corredores donde están los Templarios, dados garrote, con diferentes castigos, y con sus mantos, y en medio Jacobo de Mola agoniçando» (f. 87r). This is a visually emblematic depiction of the precarious nature of secular power.

Shakespeare's Henry IV uttered the famous lament: «Uneasy lies the head that wears a crown» (Henry IV, Part 2, Act 3, Scene 1). One of the main 
impediments to the respite of a monarch is the impossibility of knowing the truth of what is happening in his kingdom and what people really think of him. This is what motivated certain kings to disguise themselves and visit their realms at night, and what led many to place all their trust in that one confidant who might reveal unpleasant truths without fear of reprisals or repercussions: the privado, or favourite. In El hijo del serafin, San Pedro de Alcántara, the protagonist explains the fear that subjects have of sharing the truth with their monarch to King Don Sebastián:

$\begin{array}{ll}\text { Rey: } & \text { ¿Y mis priuados, y amigos? } \\ \text { Pedro: } & \text { Los amigos por testigos } \\ & \text { no valen aqui. } \\ \text { Rey: } & \text { ¿Por qué? } \\ \text { Pedro: } & \text { Porque nadie al descubierto } \\ & \text { quiere dezir vn pesar } \\ & \text { a quien pretende agradar. } \\ & {[\ldots]} \\ & \text { ¿Luego ay en el mundo quien } \\ \text { Rey: } & \text { con engaños me hable a mi? } \\ & \text { Estoy por dezir que sí, } \\ \text { Pedro: } & \text { porque si lo mira bien } \\ & \text { verá vuestra Magestad } \\ & \text { que es en las humanas leyes } \\ & \text { plaga antigua de los Reyes } \\ & \text { el no tratarles verdad. } \\ & \text { Y qué es la razón? } \\ & \\ \text { Rey: } & \text { castigo para el malsin, } \\ \text { Pedro: } & \text { para el loco, para el ruin, } \\ & \text { para el de mal proceder, } \\ & \text { para el ladrón, para el malo, } \\ & \text { y en fin por qualquier camino } \\ & \text { para cada desatino } \\ & \text { cárcel, horca, afrenta, o palo, } \\ & \text { y no auer pena, señor, } \\ & \text { para los que lisonjean, } \\ & \text { y la verdad regatean, } \\ \text { por conseruar el fauor. (El hijo del serafin, San Pedro de } \\ \text { Alcántara, f. 34r-v) }\end{array}$

Pérez de Montalbán, like many of his fellow dramatists, explored the curious relationship between princes and their seemingly untouchable and irreproachable privados in a number of plays. Spanish Golden Age spectators seemed to relish the role of vicarious observers of the rise and fall of these envied and often despised intimates of monarchs.

Open discussion of the foibles of a monarch was of course risky business, and thus plays dealing with the human failings of rulers were usually set in foreign countries or the very distant past. One such example in the dramatic repertoire of Pérez de Montalbán is El Mariscal de Virón $n^{3}$. As a high ranking

3. Parker, based on the attack of Pérez de Montalbán's Para todos penned by Quevedo in 
minister of military justice ${ }^{4}$, it is not wholly inconceivable that a mariscal might have enjoyed the confidence of the king, and thus in his dedication of the play, Pérez de Montalbán refers to the Mariscal as: «aquel Valido, el más agasajdo de su Rey, y el más valiente restaurador de su Patria, si bien malogró lo vno, y lo otro con la ambición de pensar que quien nace vassallo por naturaleza, puede llegar a Principe por maña» (El Mariscal de Virón, f. 110v).

In this play the soldier Carlos de Virón, in the service of the French King, slowly climbs the ladder of the hierarchy at court with his martial victories, adding the titles of Duque de Virón and Par de Francia. But his insatiable ambition for further honors leads him to enter into a conspiracy with other traitors to overthrow the monarch. When the plot is discovered, an unrepentant Carlos refuses to reveal the identity of his co-conspirators and is sentenced to death. The arrogant Carlos is certain that the sentence will not be carried out, for the king needs him to help preserve his hold on governance against his enemies. The pathos of the play results from the slow realization that comes over the protagonist that the lofty position he has attained will not prevent an ignominious and dishonorable public execution.

The French king tries to warn Carlos that he can fall out of favor just as quickly as he rose to power: «que el Rey se puede enojar, / y enojado hazer vaxar / al mismo que hizo subin» (f. 116v). Likewise, the Conde Suisón tries to disillusion the vainglorious Carlos: "Sombras son de la fortuna / la priuança y la caida» (f. 124v). Carlos, however, does not heed the advice, and in his death, as related by Blanca, he is an exemplary warning to others of the precarity of being a favourite. His scrupulously staged execution unfolded "al espectáculo grande / del mayor teatro, en cuya / tragedia representaua / sus mudanças la fortuna» (f. 129r). There, before the unpardoning gaze of a massive public, the Mariscal symbolizes the: "[...] lástima y exemplo / de las priuanças, que duran / lo que la vida en la rosa, / lo que en la flor la hermosura» (f. 129r). And although Pérez de Montalbán may have missed a bet by not actually staging this execution as a discovery scene, the spectacle is nevertheless described as a vivid hieroglyph of the night and death:

\section{Llegó el Duque a vn cadahalso trono infame de sus culpas, cuya máquina sublime negros ropages enlutan. Era el fúnebre aparato}

\footnotetext{
his La Perinola (1633), points out that the play is based on the historical account of the events found in Juan Pablo Mártir Rizo's Vida del duque de Virón published in 1629 (1975: 45). A satirical burlesque version of Pérez de Montalbán's play with the same title was published by Juan de Maldonado in 1658. For an analysis of this humorous refundición, see Hurtado and Mata Induráin.

4. The definition of mariscal in the 1734 edition of the Diccionario de Autoridades reads in part: "Oficial mui preeminente y principal en la Milicia, inferior solamente al Condestable. Era Juez de todo el Exército, y le tocaba, no solo castigar los delitos, sino también el gobierno económico, disponiendo los alojamientos, previniendo los abastos, y corrigiendo las medidas, y otras cosas semejantes.»
} 


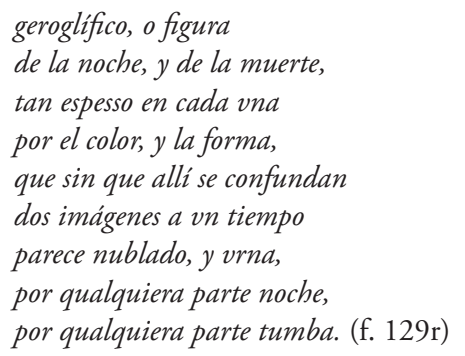

It is indeed as an emblematic figure that the privado comes to embody the collective fears and aspirations of the playgoing public. The corral de comedias was an arena where it was possible to dream with aspirations of transcending the rigid boundaries of class distinction through the vicarious experience of dramatic representation, but the tragic fate of those who aimed beyond their God-given state in life was at the same time a stark and often visually reinforced reminder of the dangers inherent in those who, like Carlos, are driven «a que

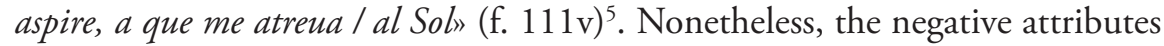
of treachery, arrogance and excessive ambition would have left the audience satisfied that Carlos received his just desserts.

The life of Felipe II provided the dramatic material for a trilogy of plays by our dramatist ${ }^{6}$. Parker indicates that El segundo Séneca de España (Para todos, 1632) covers the period 1569-1570; El señor don Juan de Austria en Madrid (Primero Tomo de las Comedias del Doctor Ivan Pérez de Montalbán, 1635) deals with the years 1571-1576) and the Segunda parte del Séneca de España, Don Felipe Segundo (Segundo tomo de las comedias del Doctor Ivan Pérez de Montalván, 1638) covers the years 1588-1598 (1975: 56). It is the play dedicated to Felipe's half-brother that touches most directly on the theme of privanza. The character who enjoys the king's favor in this comedy is Diego de Córdoba. In his subtle attempts to get the monarch to reward him for his services, Diego alludes to his situation through analogies with some of his neighbors. One of them is a philosopher who: "Es vn hombre muy preciado / de estar de ti retirado, / y de no saberte el nombre: / hase dado en lastimar / de mi, viéndome valen (f. 222v). The king responds with a barely veiled threat: "Querrá dezir, que el caer / es lo mismo que el priuar» (f. 222v). Diego however persists with his anecdote, telling the king that the philosopher, upon seeing a stone-layer at work on the pavement, proclaimed: «Solo aqueste sin rezelo / priuando en el mundo está, / pues del suelo aun no caerá, / porque está pegado al suelo» (f. 222v). And once again Felipe responds in a menacingly enigmatic fashion, assuring Diego that the vogue in Madrid for adding subterranean cuevas to houses threatens even the empedrador who trusts that he is standing on firm ground:

5. For emblematic associations of monarchs depicted with solar imagery, see Mínguez (2001). For a more thorough consideration of emblematics in the plays of Pérez de Montalbán, see Cull, "A mi no hable en emblemas» (at press).

6. For a study of the figure of Felipe II in the plays of Pérez de Montalbán, and his depiction as a symbol of political prudence and generosity, see Voinier (2010). 


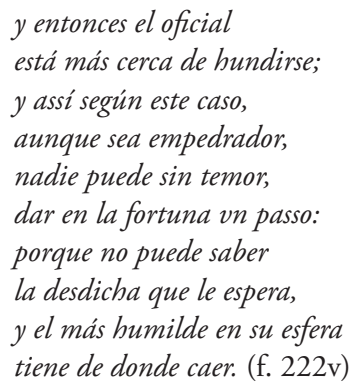

El señor don Juan de Austria en Madrid is a comedy, however, and thus the theme of privanza is secondary, with a greater emphasis placed on the image of the king as someone whose mere presence is sufficient to inspire fear, awe and respect. Indeed, the gravitas of Felipe II, and of monarchs in general, should be adequate to keep in check the excesses of the valido, as Santoyo observes in the first play from the trilogy, El segundo Séneca de España:

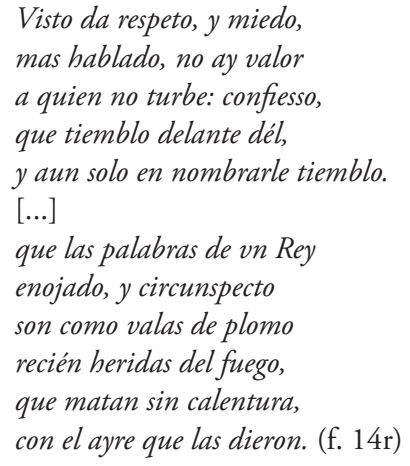

The Segunda parte del Séneca de España, Don Felipe Segundo begins, rather atypically, with a series of discovery scenes in which Felipe II reveals to prince Fernando emblematic representations of the humility with which he should embrace the duties of kingship: the portraits, coffins and tombs of his ancestors ${ }^{7}$. In a kind of emblematic subscriptio of the meaning of the visually symbolic tableaux displayed, King Philip himself observes: «y también que le sirua / en tanta pompa de freno. / Ver que estos mármores blancos launque de polbos cubiertos / vn tiempo lo fueron todo, I y ya no son lo que fueron» (f. 23v). The play concludes with the monarch's exemplary death, and when Felipe III orders Cristóbal de Mora to surrender his key to the king's retrete to the Marqués de Denia, the former laments his fall from power:

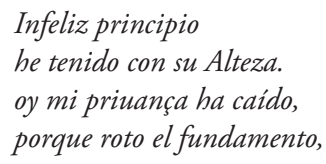

7. On the emblematic nature of many discovery scenes in Spanish Golden Age plays, see Cull (1996). 


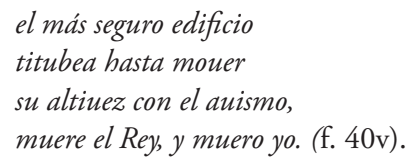

The new monarch begins his reign with the sobering realization that kingship is a painful burden: "y es vn linaje de pena / que casi toca en martirio» (f. 40v).

Another rise and fall of an overly ambitious favourite is dramatized in the historical play Amor, privanza, y castigo (also known as El fin más desgraciado $y$ fortunas de Seyano $)^{8}$. Lucius Aelius Seianus, born into the equestrian caste, exploited his friendship with Emperor Tiberius to rise to the position of Roman counsel by savagely eliminating his political enemies. But just when it seemed as though he was the most powerful man in the empire, he was denounced, arrested and executed. Pérez de Montalbán's rendition is faithful to the historical account, and in the dedication he writes: «Es el assumpto, Elio Seyano, el mayor valido que tuuo Tiberio, y el enemigo más atroz de su vida, quiçá porque le amaua tanto, que el mucho fauor, no solo haze ingratos, sino traidores» (f. 152r). Although the play does not discuss the nature of privanza directly, it comments subtly on the precarity of corrupt favorites. Sejanus himself, when his fall is imminent, ponders the significance of certain ill omens he has noticed, such as lightning:

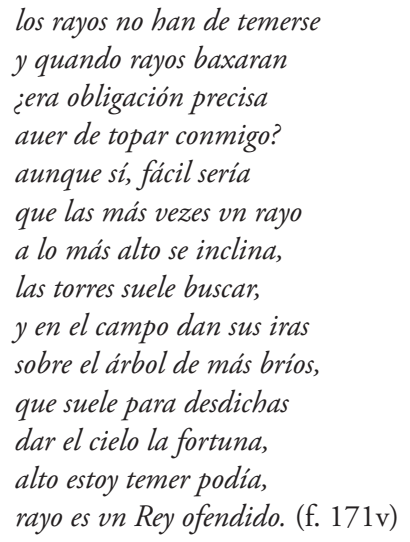

It is possible that Pérez de Montalbán is evoking here one of Juan de Borja’s Empresas morales (Prague, 1581). The emblematic pictura depicts lightning bolts toppling a tower. The motto, Celsa graviore casu decidunt (Que las cosas altas dan mayores caidas), is taken from Horace's Carminum 2.10.10. The prose commentary links the visual image and motto to the context of those whose ambitions are too lofty:

Cosa es muy ordinaria a todos los hombres del mundo trabajar, y desvelarse, por subir, y llegar al más alto, y encumbrado estado, a que su desseo les lleva, y guía, [...] y ya que alguno

8. Profeti comments that in this play Pérez de Montalbán: «si discetta con espressioni non dissimili dai coevi drammaturghi sul perfetto privado» (1970: 84). 
aya subido a essa cumbre, fácilmente es de alli derribado, por ser mayores los peligros, quanto el estado es más alto [...] Lo más seguro y mejor sería, contentarse cada uno con el estado, en que nació [...] y con esto se viviría con más quietud, y contento (Primera parte, 190-91).

The play ends with an equally emblematic discovery scene of the bloody cadavers of Seyano and Libia, justly punished: Descúbrese Seyano, sangriento, y Libia como despeñados. (f. 173v)

Other plays of uncertain attribution deal with the theme of privanza, but since they are comedies, we do not see the tragic rise and fall of the valido. Ser prudente y ser sufrido appeared in the first volume of the Comedias escogidas del Doctor don Juan Pérez de Montalván (Madrid 1837). Not all critics agree on its attribution to our dramatist. It is a play, however, that is consistent with the views on privanza expressed by the protégé of Lope de Vega in the works universally recognized as authentic. In this play Bermudo is a trusted minister of king Alfonso de León. The monarch asks him to always tell him the truth: "que a la Real Magestad, nunca llega la verdad, con el rostro descubierto" (Comedias escogidas I, 399). One of the truths that he confides is the popular rumblings over the king's choice of a privado:

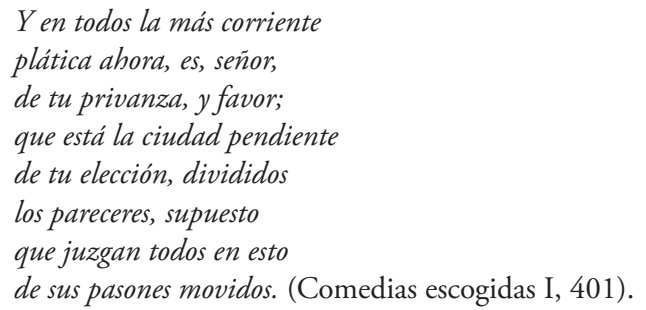

This provokes a theoretical discussion between the two men about whether or not a king should in fact have a favourite. Bermudo launches into a long discourse, beginning with Adam, who received Eve as his counselor; Christ chose San Juan as his privado. All kings since, according to Bermudo, have had favourites. The only difference is the amount of power they have enjoyed. $\mathrm{He}$ posits that it is natural to want to have a friend with whom to share secrets, since the human condition is to be an animal sociable (Comedias escogidas I, 402), and adds that just as the sun does not share its rays directly, the king needs a mediator to communicate with his subjects, since they are opposite extremes of a spectrum (Comedias escogidas I, 403). The king is thus persuaded by these arguments, although he understands the burden that the job represents to the chosen one:

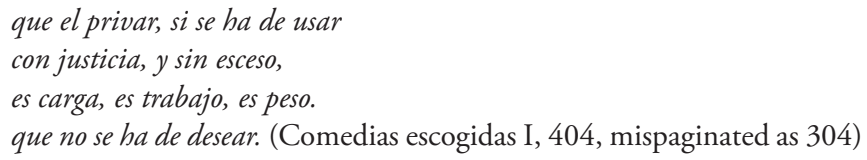

The anxiety occasioned by the king's selection of a privado is an aspect stressed in this play. The choice has consequences not only for those at court 
who compete for royal favor, but also for the populace as a whole, as Bermudo explains:

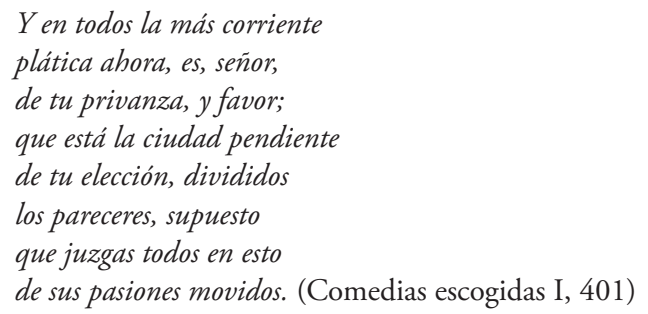

The real emphasis in this play is not on the privado, but rather on the selection process. Once again, assuming that it was indeed Pérez de Montalbán who authored it, an emblematic depiction displayed before the eyes of the beholders is crucial in revealing the king's prudence and discretion. This key moment occurs in a discovery that reveals a portrait of the king, which he hides behind in order to listen to the conversation between various pretenders for the position of privado. Diego Núnez notices that the portrait includes an inscription, the equivalent of an emblematic epigram, or inscriptio. It reads: "Cordero soy justiciero, / y pacifico león" (Comedias escogidas I, 424). In order to achieve the goal of the equitable administration of justice entailed in the enigmatic epigram and make the correct choice of a privado, the monarch needs to learn to conquer his own human needs and desires for the good of the kingdom, by suppressing his amorous passions:

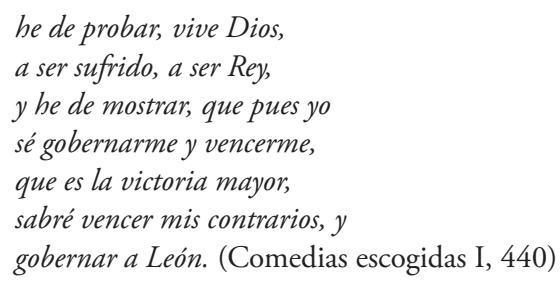

Because we are dealing with comedy rather than a tragedy, he is successful at controlling himself, and the play ends with marriages.

Another play commonly attributed to Pérez de Montalbán, published partially in the second volume of Comedias escogidas, and fully as a suelta, is Como a padre y como a rey ${ }^{9}$. Conrado, the privado of the king of Sicily, wants to pass the mantle down to Carlos, who he has raised as his son. Carlos accepts the role as favourite only grudgingly, aware that he will be disliked merely for being the king's confidant:

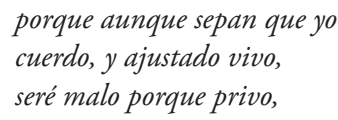

9. Cañas Murillo deals briefly with this play as one which develops a series of ideas «sobre el ejercicio del poder, se va a ofrecer un doctrinal de privados, un conjunto de consejos para el buen gobierno de un pais» (2006: 106). 
y bueno el que ayer privó.

$Y$ si el mundo nunca ha visto,

ni el tiempo nos lo ha enseñado,

haberse otra vez juntado

ser privado y ser bien quisto,

no es mucho que el alma tuerza

de su gusto al parabién,

pues aun procediendo bien,

he de ser malo por fuerza. (Comedias escojidas II, 14)

The monarch, however, persuades him that even a king must have a friend with whom to share his passions, and then offers advice on how to perform his duties well:

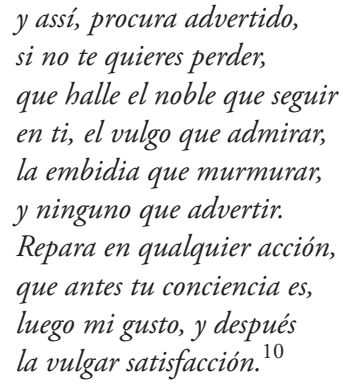

Before the king reveals Carlos's true identity to his son, the monarch puts him to the test in his role as privado. The king is particularly delighted to find out how Carlos deals with court pretenders, observing his decisions in hiding al paño:

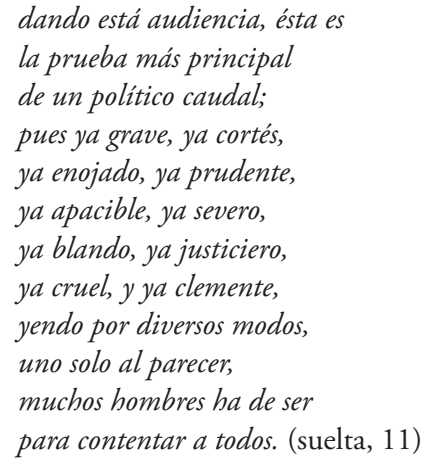

Another play published only in a suelta and attributed to Pérez de Montalbán is La ventura en el engaño ${ }^{11}$. Here a former favourite of King Juan III of Portugal, Don Juan de Alencastro, has retired to a quiet life in the countryside,

10. The text in the Comedias escogidas edition is corrupt, substituting text from another play (El yerro del entendido by Juan de Matos Fragoso, whose first volume of Comedias escogidas was also published by Ortega in 1828) for the text by Pérez de Montalbán. This quote is cited from the suelta edition, available at the Cervantes Virtual website, page 2.

11. Parker does not deal with this play at all, but Bacon concurs with La Barrera and Schack that «Montalbán gas a strong claim to authorship» (1912: 450). 
disillusioned with the pretense of court and the dearth of compensation for all the services that he has rendered: «que quantos gustos se ofrecen / en la Corte y glorias falsas, / que las priuanças del mundo / son imagen de inconstancia» (Act 1 , unpaginated). In the context of a party game where the disguised king is playing the role of «king», Alencastro is allowed to air his grievances without fear of retribution:

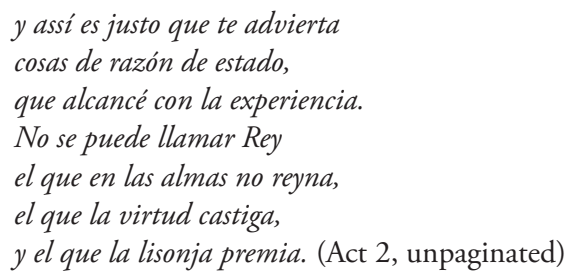

King John takes to heart the advice and reaffirms the prudence of a monarch disguising himself on occasion to find out the truth of what his subjects think of him: "O quanto importa a los Reyes; / que con disfraz se entretengan, / por las Ciudades mirando / los que con razón se quexan» (Act 2, unpaginated).

Another play most likely penned by Pérez de Montalbán ${ }^{12}$ that deals with the theme of privanza is El valor perseguido y la traición vengada. Here the perfidious Conde Arnesto is the favourite of the King of Naples. He concocts a scheme to rob the infanta Matilde of her honor by pretending to be another. He later attempts to violate Octavia, daughter of the Duque de Ferrara. In trying to cover up his misdeeds and keep the king from discovering his treachery, Arnesto utters the proverb that symbolizes the precarity of his position: $« M i$ vida / anda de un hilo pendiente» $(15)^{13}$. And in the end he does indeed pay the consequences for his treachery.

What is unique in this play is that the gracioso Martín, the servant of Arnesto, assumes the role of the favourite of his master, thus presenting the perils of privanza in a satirical vein. He tells his fellow gracioso Durón that he should no longer address him «Tú por tú con Don Martín / el privado del privado» (15). What is more, he counsels:

$$
\begin{aligned}
& \text { Y si queréis negociar } \\
& \text { qualquier cosa de importancia, } \\
& \text { habladme con memorial, } \\
& \text { que soy hombre principal, } \\
& \text { desterrad vuestra ignorancia. } \\
& \text { Quedad con esto instruido } \\
& \text { del modo que veis de hablar } \\
& \text { a quien tiene tal lugar, } \\
& \text { y está tan favorecido }
\end{aligned}
$$

12. See Bacon (1912: 450) and Parker (1975: 65-66).

13. Correas registers this version of the proverb: "Colgado de un hilo. (Estar en peligro; lo que colgado de los cabellos).» A variant is found in another play attributed to Pérez de Montalbán: «El alma tengo en un hilo" (Comedias escogidas II, Como a padre y como a rey, 14, Cervantes Virtual edition). 
como yo, necio indiscreto,

inhábil tontorrontón,

Don Martin soy, muy Don,

y Don de mucho respeto. (15)

As the typically arrogant Spaniard (at least in the eyes of his Italian hosts), Durón learns a lesson of humility from the pompous behavior of Martín:

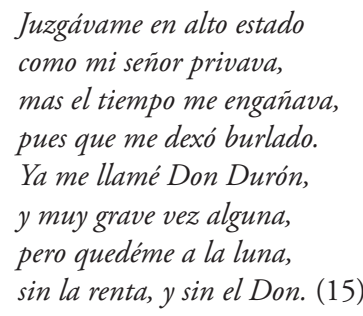

Other plays attributed to or written by Pérez de Montalbán deal with the rise and fall from grace of a protagonist who would have been known to the spectators, but space limitations preclude their thorough consideration here. Some of these include El valiente Nazareno (also known as El divino nazareno Sansón / Los hijos de la fortuna, included in the Segundo tomo), La lindona de Galicia and the two part play, La puerta Macarena. There are also plays where the trajectory is reversed and a protagonist of humble origins or loose morals rises to fame and honor, such as Don Florisel de Niquea (Segundo tomo), Teágenes y Clariquea (Segundo tomo), Palmerin de Oliva, La gitana de Ménfis, Santa María Egipciaca and La mudanza en el amor.

In a theocentric world obsessed with justice, both secular and divine, the individual who enjoyed the confidence of the monarch was under constant scrutiny by those who feared that he might abuse his authority. Proximity to power brought great rewards and great peril, as Rodrigo observes in La puerta Macarena. Primera parte:

$$
\begin{aligned}
& \text { Otro dixo, que era el Rey } \\
& \text { como el fuego, y no decía } \\
& \text { mal, que de lexos calienta, } \\
& \text { y de cerca abrasa. (20) }
\end{aligned}
$$

Juan Pérez de Montalbán's treatment of the precarious nature of the politics of power and authority, in conclusion, is most original and effective in those plays where the message is conveyed both visually and through the dialogue in an emblematic discovery.

\section{Bibliography}

Atienza Belén, «Arte y privanza en La quinta de Florencia de Lope de Vega: De los Médicis al Duque de Lerma», Bulletin of the Comediantes, 61.2, 2009, pp. 1-18. Bacon George William, The Life and Dramatic Works of Doctor Juan Pérez de Montalván, Paris, Klincksiek, 1912. 
Borja Juan de, Empresas morales, ed. Carmen Bravo-Villasante, Madrid, Fundación Universitaria Española, 1981.

Bradner Leicester, "The Theme of privanza in Spanish and English Drama 15901625», in Homenaje a William L. Fichter:Estudios sobre el teatro antiguo hispanico y otros ensayos, Madrid, Castalia, 1971, pp. 97-106.

Campell Ysla, «El poder y la privanza: las propuestas de Alarcón», eHumanista, 32, 2016, pp. 201-219.

Cañas Murillo Jesús, «Lenguaje y personaje en el teatro de de Juan Pérez de Montalbán», in Culteranismo e teatro en el teatro nella Spagna del Seicento. Atti del Convengo Internazionale. Parma, 23-24 aprile 2004, A cura di Laura Dolfi, Roma, Buizoni Editore, 2006, pp. 101-115.

Carreño-Rodríguez Antonio, «Privanza e integridad nacional: Lope de Vega y las crisis del poder», RILCE: Revista De Filología Hispánica, 21.2, 2005, pp. 205-225.

Correas Gonzalo, Vocabulario de refranes y frases proverbiales y otras fórmulas comunes de la lengua castellana, Madrid, Jaime Matés, 1906.

Covarrubias Sebastián de, Tesoro de la lengua castellana o española, ed. integral e ilustrada de I. Arellano y R. Zafra, Madrid, Iberoamericana, 2006.

Cull John T., "Hablan poco y dicen mucho: The Function of Discovery Scenes in the Drama of Tirso de Molina», The Modern Language Review, 91.3, July, 1996, pp. 619-34.

- "A mi no hable en emblemas. The Function of Emblematics in the Plays of Juan Pérez de Montalbán", at press.

De Armas Frederick A. «En dos pechos repartidos’: Felipe IV y su valido en Cómo ha de ser el privado» Hispanófila, 140, 2004, pp. 9-20.

Diccionario de Autoridades, Real Academia Española, ed. facsímil. Madrid, Gredos, 1990, 3 vols.

Ferrer Valls Teresa, «El juego del poder: Lope de Vega y los dramas de la privanza», in Modelos de vida en la España del Siglo de Oro, I: El noble y el trabajador, Madrid, Spain; Frankfurt, German, Iberoamericana; Vervuert, 2004, pp. 159-185.

Greer Margaret R. and Andrea Junguito, «Economies of the Early Modern Stage», Revista Canadiense de Estudios Hispánicos, 29.1, Otoño 2004, pp. 31-46.

Hernández Araico Susana, «Pintura y estatismo teatral en la comedia Cómo ha de ser el privado», Insula: Revista de Letras y Ciencias Humanas, 648, 2000, pp. 30-32.

Hurtado Milena M. and Carlos Mata Induráin, «Algo más sobre comedia burlesca y Carnaval: a propósito de El Mariscal de Virón, de Juan de Maldonado», eHumanista, 2, 2002, pp. 161-75.

La autoridad política y el poder de las letras en el Siglo de Oro, eds. Jesús M. Usunáriz and Edwin Williamson, Madrid y Frankfurt am Main, Universidad de Navarra, Iberoamericana y Vervuert, 2013.

Mínguez Víctor, Los reyes solares. Iconografía austral de la monarquía hispánica, Castelló de la Plana, Publicacions de la Universitat Jaume I, 2001.

Oriel Charles, "The Play of Presence and Absence: Writing and Supplementarity in the comedias de privanza», in El arte nuevo de estudiar comedias: Literary Theory and Spanish Golden Age Drama, Cranbury, NJ, Bucknell UP; Associated UP, 1996, pp. 36-51. 
Parker Jack Horace, Juan Pérez de Montalván, Boston, Twayne, 1975.

Peale C. George, "Comienzos, enfoques y constitución de la comedia de privanza en la Tercera parte de las comedias de Lope de Vega y otros auctores», Hispanic Review, 72.1, 2004, pp. 125-156.

Pérez de Montalbán Juan de, Comedias escogidas del Doctor Juan Pérez de Montalván. Tomo Primero, Madrid, Imprenta de Ortega y Compañía, 1827.

- Comedias escojidas del Doctor Juan Pérez de Montalván. Tomo Segundo, Madrid, Imprenta de Ortega, 1831.

- Como a padre y como a rey, Valencia, Imprenta de Joseph y Thomàs de Orga, 1781.

- El valor perseguido, y trayción vengada, Salamanca, Imprenta de la Santa Cruz. No Date.

- La puerta Macarena. Primera parte. Sevilla: Imprenta de Joseph Padrino, No Date.

- La ventura en el engaño, Suelta from the collection of the Biblioteca Menéndez Pelayo, Sig. 32762, No Place, No Publisher, No Date.

- Primero Tomo de las Comedias del Doctor Ivan Pérez de Montalbán, Clérigo Presbitero notario del Santo Oficio de la Inqvisición, y natural de Madrid, Alcalá de Henares, Imprenta de Antonio Vázquez, Impressor de la Vniversidad, 1638.

Política y literatura. La razón de Estado en las letras del Siglo de Oro, ed. Enric MallorquíRucalleda, eHumanista 31, 2015, pp. 276-488.

Profeti Maria Grazia, «Funciones teatrales y Literarias del personaje del privado», in Dramaturgia festiva y cultura nobiliaria en el Siglo de Oro, Madrid, Spain; Frankfurt, Germany, Iberoamericana; Vervuert, 2007, pp. 133-150. Rpt. in La Représentation du favori dans l'Espagne de Philippe III et de Phillipe IV, Paris, Sorbonne Nouvelle, 2010, pp. 113-129.

- Montalbán: um commediografo dell' età di Lope, Pisa, Università di Pisa, 1970.

Quevedo Villegas Francisco de., El buscón, ed. Domingo Ynduráin, Madrid, Cátedra, 1980.

Ridout Nicholas and Rebecca Schneider, «Precarity and Performance: An Introduction», The Drama Review, 56.4, Winter 2012, pp. 5-9.

Sáez Adrián J., "De la privanza en Calderón: Los cabellos de Absalón y La hija del aire», Bulletin of Spanish Studies: Hispanic Studies and Researches on Spain, Portugal, and Latin America, 92.2, 2015, pp. 167-177.

Voinier Sarah, «La figura de Felipe II en el teatro de Juan Pérez de Montalbán», in Actas del XVI Congreso de la Asociación Internacional de Hispanistas: nuevos caminos del hispanismo--: Paris, del 9 al 13 de julio de 2007, Madrid and Frankfurt, Iberoamericana; Vuivert, 2010, Unpaginated.

Weimer Christopher, «Lovesickness and Politics: Privanza as Pharmakon in Tirso's Privar contra su gusto», RLA: Romance Languages Annual, 10.2, 1998, pp. 853-858.

— "The (Homo)Erotics of privanza: The Count of Villamediana and Tirso's Privar contra su gusto", in Lesbianism and Homosexuality in Early Modern Spain: Literature and Theater in Context, New Orleans, LA, UP of the South, 2000, pp. 257-279.

Wise Carl A., "Eclipsed Autonomy: Celestial Images and the Free Will Debate in Antonio Mira de Amescua's Álvaro de Luna Plays», Bulletin of the Comediantes, 66., 2014, pp. 109-122. 